\title{
Some Aspects of Growth in the Netherlands 1970-1998 An International Comparison*
}

\author{
Hugo Hollanders \\ MERIT, Maastricht University \\ Tel.31-43-3883873, h.hollanders@merit.unimaas.nl \\ Thomas Ziesemer** \\ Department of Economics \& MERIT, Maastricht University \\ Tel.31-43-3883872, t.ziesemer@algec.unimaas.nl
}

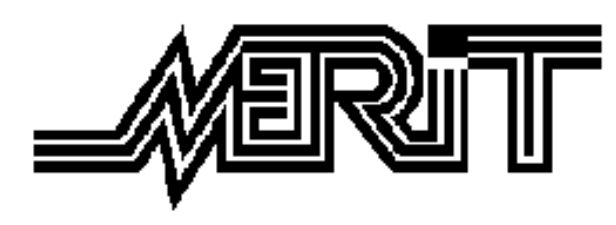

Maastricht Economic Research Institute on Innovation and Technology, Maastricht University, P.O. Box 616, 6200 MD, Maastricht, The Netherlands.

\footnotetext{
* This paper is the written and extended version of a presentation given at the Max-Planck Institut für Sozialforschung, Cologne, November 1998. This paper has benefited from comments received by participants at a seminar at Maastricht University. We are also grateful to Huub Meijers for a useful discussion. Responsibility is entirely ours.

${ }^{* * *}$ Corresponding author.
} 


\section{Introduction}

This paper presents some information on issues that have some importance for those who try to learn from the economic policy of the Netherlands. In particular we discuss the following questions.

i) Does growth in the Netherlands differ from that of other Western European countries?

ii) In which branches and sectors is the GDP of the Netherlands and Germany produced (Share of metal, services etc.)?

iii) What was the impact of wage policy on the innovative capabilities in the Dutch industry?

iv) What is the impact of wage moderation on productivity?

Each of these questions is treated in one of the sections 2-5. In section 6 a policy view is presented. Section 7 summarises.

\section{FIGURE 1 OVER HERE}

\section{GDP growth in the Netherlands compared to other Western European countries}

As some Germans want to learn from the Dutch experience we start with a comparison of German and Dutch GDP growth rates for the years 1970-1998 as plotted in Figure 1. The whole period is divided into sub-periods by vertical lines drawn in Figure 1. In the sub-period 1970-1975 in some years Dutch growth rates are larger than the German growth rates and in other years it is the other way around. In the period 1976-1983 Dutch growth rates are lower throughout. Between the wage agreement of 'Wassenaar' (1983) and the German Unification the Netherlands have higher or equal growth rates with the exception of the year 1988. However, an alternative way of reading the data is to say Dutch growth rates were higher for 3 years after 1983 and from 1987-1990 there is a changing pattern again. From 1993 until 1998 Dutch growth rates are higher. This is the period after Prime Minister Lubbers had shifted more emphasis of Dutch policy towards the reduction of the wage wedge, the difference between gross and net wages. The employers' part of the wedge has been decreased more strongly than that of the employees. ${ }^{1}$

\footnotetext{
${ }^{1}$ See van Veen (1997), chapter 6.
} 


\section{TABLE 1 OVER HERE}

For the period after 1983 the question arises whether the higher growth is due to wage moderation or just to the fact that these are the years after the world recession which effects small countries more than large countries. In more drastic words, one could hypothesise that the relatively weak Dutch growth performance before 1983 is due to the weak world economic situation, which affects the small Netherlands more than the large Germany. Similarly, the relatively strong growth after 1983 could stem from the upswing - after the 1982 low of the world economy - affecting the small Netherlands more favourably than the large Germany. If these hypotheses were correct a comparison of the Netherlands with smaller countries should be less favourable than with the large Germany. This comparison is made in Table 1. Table 1 considers the GDP growth rate of the country mentioned in the pre-column minus the GDP growth rate of the Netherlands. The dark parts in the table are those where the result is negative, which means that the Netherlands had higher growth. To repeat, the comparison with Germany (denoted DEU in the table) yields a negative value for 1984-87 indicating higher Dutch growth after the 1982 recession. The comparison with Belgium and Austria, the country that has invented its own form of wage moderation after WWII, is only slightly less favourable. The comparison with Denmark, Sweden and Norway is much less favourable. The reason for the latter result, however, is the strong development of the UK, which is well known to have its own business cycle and a strong impact on Denmark. Norway is strongly dependent on oil prices and the value of the US dollar. The comparison with Belgium and Austria therefore seems to be more to the point. Ultimately, it seems impossible to argue that the relative Dutch performance around 1983 is merely due to country size effects, but it is also clear that Dutch growth performance after 1983 is much less strong when the comparison is made with respect to smaller countries.

What is more impressive though when looking at Table 1 is the great difference in relative Dutch growth performance before 1989 and after 1989. After 1989 Dutch growth outperforms that of other countries with only few interesting exceptions. One is the German Unification in 1991. Denmark starts its own policy of wage moderation in 1993 and has some relatively good years 1993-1995. These years, however, are also relatively good years in the UK, which might have pulled the Scandinavian countries. The strongest exception, however, 
is Norway with five years of stronger growth. Four of these years are years of increasing oil prices.

Kleinknecht (1998) in his Figure 3 presents data showing that from 1984 to 1993 the Netherlands had higher growth rates of GNP than the average of the EU-15 except 2 years.

Our interpretation of these data is that growth has been relatively strongest after 'Wassenaar'/1983 and after the policy against the wedge in the early 1990s. It seems hard to deny that these events have been causal although the differential impact of country size is present after 1983 when the resumption of world economic growth did contribute to small countries' growth more than that of large countries. In the 1990s this aspect of world economic growth seems to be less relevant. After the German Unification the wage wedge is decreased in the Netherlands and increased by the German government.

\section{FIGURE 2 OVER HERE}

\section{In which sectors and branches is the GDP of the Netherlands and Germany pro- duced?}

It can be seen from figure 2 that the Netherlands does have a higher share of services as a percentage of GDP than Germany, but a lower one than the US. In agriculture ${ }^{2}$ the ranking is US, Netherlands and Germany. Industry's share is about equal in the US and the Netherlands, but Germany has a higher than these countries.

The shares concerning employment ${ }^{3}$ are slightly different as can be seen from Figure 3. The Netherlands has a higher share than the US although in GDP it is the other way around. For services and industry the ranking is the same as it was concerning output.

Overall, the greatest remarkable difference is in the share German industry has in GDP and employment compared to these countries. However, we will come back to the development of services later.

\section{FIGURE 3 OVER HERE}

\footnotetext{
${ }^{2}$ Defined as ISIC 1 (agriculture, hunting, forestry and fishing) and ISIC 2 (mining and quarrying).

${ }^{3}$ Defined in full-time-equivalents (FTEs).
} 
When looking at the share of the metal industry in Figure 4 it is obvious that it is higher in Germany than in the other two countries. For Germany this share is about twice as large as that of the Netherlands and about 50\% larger than that of the USA. It is decreasing in Germany only after the Unification. Together with the high export share in production of the metal industry this partly explains the strong position of the metal unions in Germany as far as this is based on market forces. In the Netherlands there are no unions of similar strength. The relative strength of the unions may be an important aspect in explaining the difference in the inclination to agree to a policy of wage moderation when trying to understand the Dutch model. The policy of checks and balances has given relatively little power to unions in the Netherlands - a fact that can not be ignored when trying to learn from the 'Polder model'. The plots do not show any structural beggar-thy-neighbour impact of Dutch policy on German sectors. The phenomenon seems to be limited to the border regions.

\section{FIGURE 4 OVER HERE}

\section{What was the impact of wage policy on the innovation capabilities in the Dutch in- dustry?}

Figure 5 shows R\&D of some sectors as a share of the value added of that sector. In all four cases shown this share is developing fairly smoothly in German industries and until 1983 parallel to the Dutch number with the exception of ISIC 37, the smaller part of the metal industry. But it is getting a strong boost in the Netherlands from 1984-1987. Afterwards it is getting back almost to the level of the 1970s for industry as a whole and for ISIC $38 .{ }^{4}$ In both of these cases it is going below the German shares whereas in ISIC 37 it is diverging from the German shares in the upward direction. Whereas it cannot be excluded that the early boost is due to 'Wassenaar', it is hard to see how the later long-run differences between the sectors can be explained by the early macro policy.

\section{FIGURE 5 OVER HERE}




\section{What is the impact of wage moderation on productivity?}

The major attack on the 'Polder' model has come from productivity analysis. Kleinknecht (1998) in his Table 1 presents data telling that

i) since 1986 annual percentage growth of value added per employee is almost half of what it was from 1981-85;

ii) it is only 50\% of productivity growth of the EU-15 since 1986.

Productivity analysis deserves special attention therefore. The major aspect is whether productivity should be measured per employee or per hour. Figure 6 presents data on productivity per employee (in FTEs) and Figure 7 per hour. The upper part of both figures looks at the large countries, the lower part at the small countries.

\section{FIGURE 6 OVER HERE}

Productivity per employee is highest in the US in the whole period. All other countries seem to catch up with the US, maybe with the exception of the UK. Among the small countries the Netherlands is the leader in the seventies, about equal with Belgium from 1980-86 and falls behind Belgium afterwards but remains more productive than the other small countries. Figure 6 for productivity per employee indeed reflects a slow down in productivity.

\section{FIGURE 7 OVER HERE}

When looking at productivity per hour one can see from Figure 7 that the Netherlands leapfrog the US in 1983, France does so in 1987 and West Germany catches up around 1991 but Germany as a whole falls behind due to the Unification. Moreover, looking at the slope of the Dutch time series we see here that the productivity slow down is much less, if any, in terms of per hour productivity (See Table 2) - with the exception of the jump from 1993-94. Again with the exception of 1994 Dutch productivity per hour is larger than that of Belgium which it was not when measuring productivity per employee. The remaining slowdown of

\footnotetext{
${ }^{4}$ ISIC 38 is 'Manufacture of fabricated metal products, machinery and equipment'. ISIC 37 is 'Basic metal industries'.
} 
productivity per hour is quite natural in the sense that less productive people have been reintegrated into the production process after they had been taken out before. ${ }^{5}$

\section{TABLE 2 OVER HERE}

Interesting aspects are revealed when looking at productivity at the sector level. Figure 8 shows that in Germany productivity per employee is higher in services and lower in industry when compared to the total. In the Netherlands and the US this is also the case during the early or middle of the 1980s but then industry and services reverse their positions which they do not do in Germany. Probably this is an effect supported by wage moderation but clearly setting in much before 'Wassenaar' in 1983. The service sectors of the Netherlands and the US have added more and more low productivity jobs. This is an important aspect because German employers tend to believe that wage moderation would increase the number of jobs in industry whereas general equilibrium effects may induce structural change creating jobs in services. Clearly, it reduces the incentive for industry unions to agree with wage-moderation policies if new jobs are created in services rather than their own industry.

\section{FIGURE 8 OVER HERE}

In particular, all curves are fairly smooth. No kinks are generated by Dutch policies. Beggar-thy-neighbour effects are clearly limited to the border regions. Given the size of the countries this may be different if Germany changes its policy.

\section{A Policy View}

There are several aspects, which make it difficult to transfer the Dutch model to Germany.

When trying to judge about the feasibility of the Dutch policy for Germany it seems to be important to be aware of the fact how costly this is. Unit wage costs relative to those of Germany have been decreasing by $35 \%$ but net wages show a difference of only about $10 \%$. In more detail, relative unit labour costs from 1.05 to 0.7 , which is a $35 \%$ reduction. ${ }^{6}$ The change in the difference of the unemployment rate is $5.7 \%$ : The Dutch rate of unemployment

\footnotetext{
${ }^{5}$ See de Neubourg and Slabbers (1992).
} 
has gone from $9.7 \%$ in 1983 to $6.3 \%$ in 1996 , a reduction by $3.4 \%$. For Germany the corresponding numbers are $7.7 \%$ and $9.0 \%$, an increase by $2.3 \% .^{7}$ This boils down to requiring a $6 \%(35: 5.7)$ decrease in relative unit labour cost in order to get a $1 \%$ decrease in the difference of unemployment rates. This is a fairly expensive policy. It is even more expensive to the extent that the gains in employment rates have to be attributed to other development such as world economic growth or labour time reduction. In short, increasing employment through wage cost reduction is very expensive. On the other hand German industries are in markets of high quality. The skills of workers are higher than in other countries. In these market segments they can charge higher prices than in low quality markets. A decrease in costs has a larger impact on prices in Dixit-Stiglitz type of monopolistic competition models for differentiated products: $\mathrm{dp}=\mathrm{dc} / \vartheta, \vartheta<1$. The multiplicative mark-up is larger the less perfect competition is. Cost reductions are more strongly translated into price reductions. The latter are more strongly translated into demand increases than under perfect competition if demand functions are of the CES type rather than of the linear type. The CES or log linear type of demand functions is what empirical investigations support.

The standard argument in favour of employment policy is that an increase in employment can be considered to be a Pareto improvement, saying that everybody can be made better off. The crucial question in negotiations is whether everybody is actually made better off. Going to Dutch net wages would imply a reduction of them in spite of the fact that a large part of the reduction in Dutch wage costs has been achieved by a reduction of the wedge. This actually means that going to Dutch net wage levels German workers would not benefit from the policy although they could if a Pareto improvement could be achieved. Instead of participating they would pay the bill. It seems fairly clear that there will be no employment gains in Germany if the negotiators are not able to make sure that everybody gains. This requires a reduction of the wedge.

A third difficulty arises from the similarity in thinking between the former union leader Kluncker and the Dutch Prime Minister Lubbers. Kluncker pushed for wage increases for low skilled people going beyond productivity increases. In all likelihood his policy is responsible for a lot of low productivity jobs that have been lost or not created. Dutch policy has created a similar problem during the wage moderation policy. Wage increases have been moderated partly irrespective of the skills and the Dutch have a pertinent shortage of high skills

\footnotetext{
${ }^{6}$ See Muysken (1998).

${ }^{7}$ See Hassel (1998).
} 
and are unwilling to solve this by wage policy. ${ }^{8}$ The most recent variant of this policy was to ask wage earners in industry for solidarity with those in the government sector. The reason was that the latter should not get higher wages according to the plans of the Dutch government in spite of the fact that the Netherlands have come close to their NAIRU and, of course, workers have now to participate in the gains from productivity enhancement. Clearly, the shortage of high skills is part of the explanation of the slow down of productivity growth. It is also clear that if there will be any wage moderation in Germany it will not take place in the segments of scarce skills. Germany will clearly prefer going to a differentiated labour market policy above a policy that tries to reduce wages in labour market segments where there is actually scarcity - however unpopular this may be at the moment. In short, Germany will prefer a transition towards a differentiated wage policy in the spirit of Pareto above a transition from a Kluncker to a Lubbers type of undifferentiated wage policy?

What might the compromise look like? Employers get lower gross wage costs and offer more employment. The government gets more employment and decreases the taxes for the low-skill, low-wage workers. Employees get higher net wages and more safe jobs but lower wage increases to the extent that their labour market segment has higher unemployment. As most of the jobs can be created in the low productivity, low skills sectors, wage moderation policy will probably be concentrated in the services sector. The role of the service sector seems to be somewhat under-emphasised in the "Bündnis für Arbeit" until now.

Labour markets could be differentiated according to the unions' and employers' federation responsible, regions, skills offered and required, scales of salaries and other things. Differentiation according to firms, however, seems to be a non-viable concept. It creates problems of asymmetric information about costs and revenues of the firm. Even accountants working for the unions will have the same problems and are no way out. This is well known from the profit-sharing debate. All types of unanimity problems have to be expected under asymmetric information. Statistics from the labour office do not suffer from this disadvantage and seem to be a better basis for the differentiation.

The major change in the responsibilities will be that the government takes over responsibility for issues of equality and justice from the Labour Unions, which they were not willing to leave to the previous government. Another implication of the concept is that in labour markets with unemployment gross wages decrease, and net wages do not increase, whereas in

\footnotetext{
${ }^{8}$ See Gelauff (1998). He argues that labour time reduction has reinforced the scarcity of highly skilled labour.
} 
labour markets without unemployment gross and net wages are increased in accordance with productivity enhancement, inflation correction and some necessary modifications.

It is obvious that government financing of this concept leaves no room for other expansive measures like expansive family policies, reduction of high tax brackets, and shorter working hours. The government will have to postpone other expenditures until the policy creates more jobs and more taxpayers, which will partly compensate for the tax reductions. Moreover, labour time shortages could be conflicting with financing old age insurance. It should be kept in mind that in the Netherlands the highest tax rate of $60 \%$ is applied at a taxable income of about fl. 100,000. This means that the rate is higher than in Germany. It is applied to lower incomes than the top taxes in Germany are. And it is simply not true that Germany has the highest income taxes in Europe. High tax rates are essential in financing employment policies.

It is also clear that innovation should not be pushed by high wages at the cost of creating unemployment. Moreover, R\&D policy should not be expected to create jobs. R\&D expenditures are no more than 2 or $3 \%$ of GDP. Changes of them can not be expected to reduce the unemployment problem, which has an order of magnitude of about 2 or $3 \%$ of GDP itself. ${ }^{9}$ Returns of innovation policy could be stretched over 40 years.

\section{Summary}

Before 1982 the Netherlands did grow 8 years slower and after 1982, when the world market lend a helping hand, three years faster than Germany did. However, Dutch relative growth performance is very strong after 1989, when the reduction of the wage wedge was emphasised by policy.

Industry in general and the metal industry in particular are much stronger in Germany than in the Netherlands. Correspondingly the unions are also stronger in Germany. 'Beggarthy-neighbour' effects seem to be limited to the border region of Germany and the Netherlands.

The R\&D intensity becomes cyclical after 1983.

\footnotetext{
${ }^{9}$ Assume that unemployment goes from $10 \%$ to $5 \%$. With a labour elasticity of production of 7 this would create an increase in GDP of 3.5\%. Taking into account that the newly employed have a lower productivity, one gets an order of magnitude of 2 or $3 \%$.
} 
Labour productivity in the Netherlands, starting from a high level, grows more slowly during the period of wage moderation. However, when measured per hour the slowdown is fairly limited.

In the Netherlands and the US labour productivity of services goes from the highest to the lowest position from 1978 - 1995. That of the industry increases.

In Germany labour productivity of services is higher than in other sectors for the whole period 1970-98. Seemingly there are not many low wage, low productivity jobs. If this structural difference is due to wage moderation in the other countries, it is plausible that wage moderation in Germany would add low productivity jobs in labour-intensive services rather than in industry.

\section{Data sources}

OECD, Analytical Business Enterprise Research and Development (ANBERD).

OECD, International Sectoral Database (ISDB).

OECD, Main Science and Technology Indicators (MSTI).

OECD, Structural Analysis Database (STAN).

The labour productivity data in Figure 7 are updated for Belgium (1983-94), the Netherlands (1988-90, 1992-94) and the United Kingdom (1993-94) using de Neubourg (1998). 


\section{Literature}

Gelauff, G.M.M., Löhne, Arbeitszeit und Institutionen, Der niederländische Arbeitsmarkt in den vergangenen Jahrzehnten, mimeo, October 1998.

Hassel, A., Das niederländische Modell, mimeo, November 1998.

Kleinknecht, A., Is labour market flexibility harmful to innovation, Cambridge Journal of Economics, 1998, 22, 387-96.

Muysken, Joan, Job growth and social harmony - Reflections on the Dutch Polder Model, mimeo, April 1998.

Neubourg, de Chris, Productivity below Sea-Level: Economic Leadership and market distortions-led Productivity Growth 1973-1994, mimeo 1998.

Neubourg de, Chris and Maureen Slabbers, The rise of small powers: Explaining Productivity Growth Since 1973, mimeo 1992.

Veen, van Tom, Studies in Wage Bargaining, Universitaire Pers Maastricht, 1997. 
Figure 1 Dutch and German GDP growth, 1970 - 1998

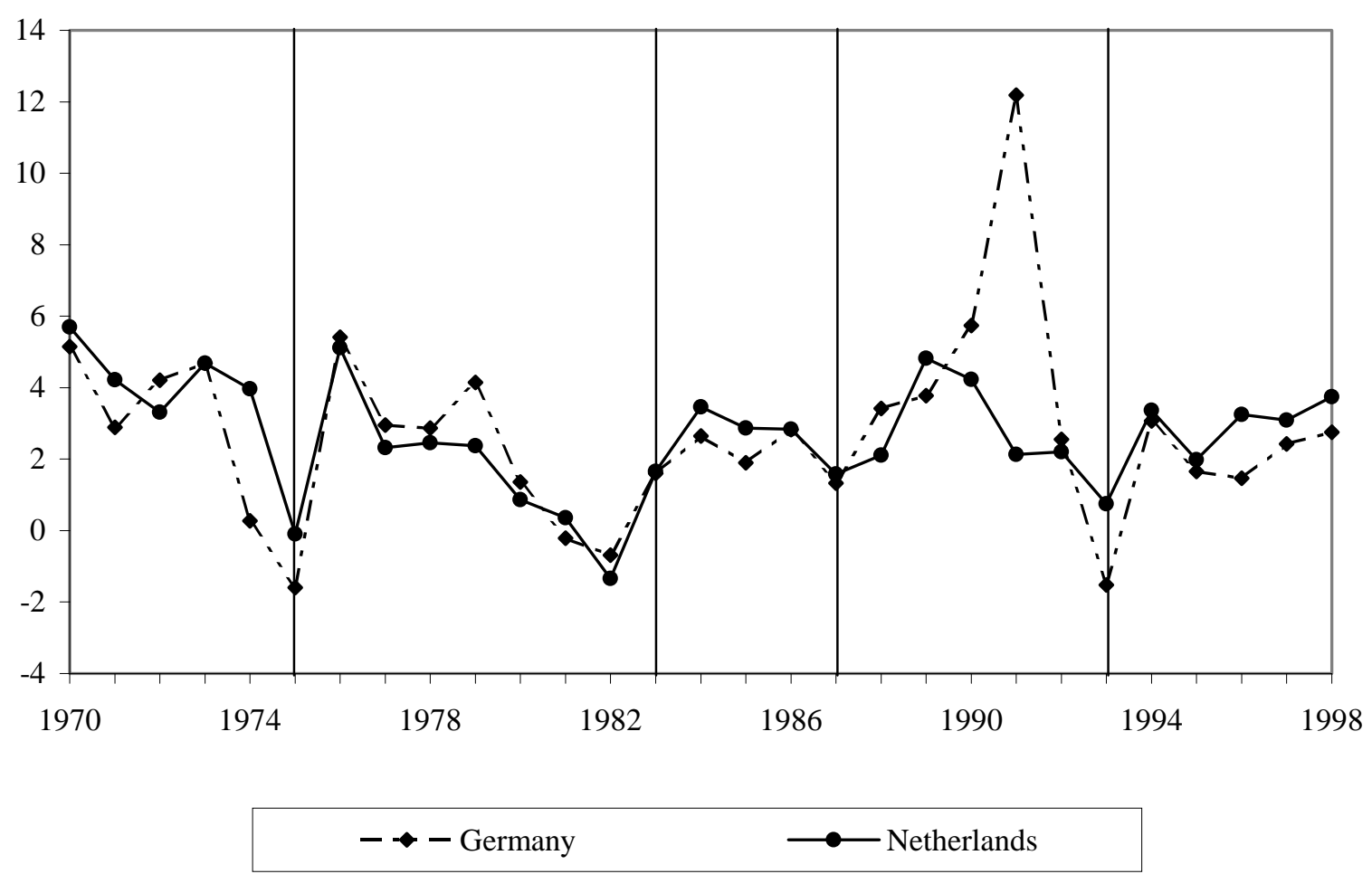


Figure 2 Sectoral GDP shares, 1970-1995

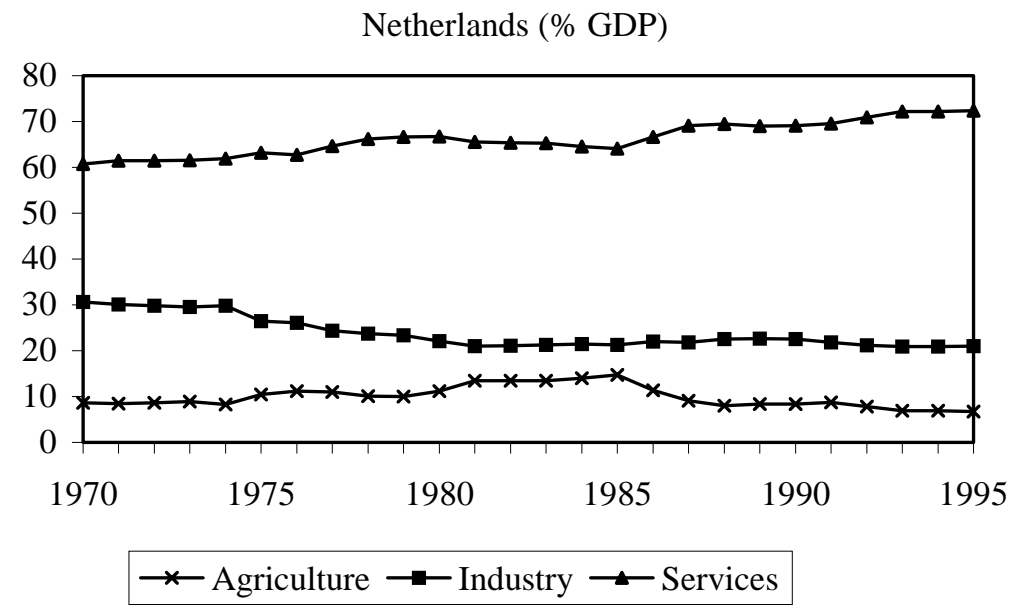

Germany (\% GDP)

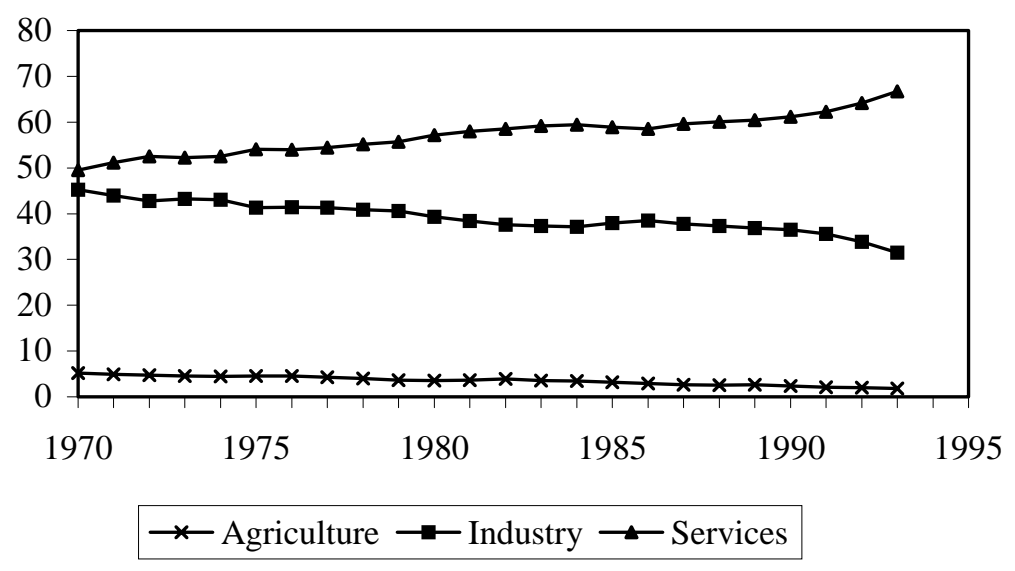

United States (\% GDP)

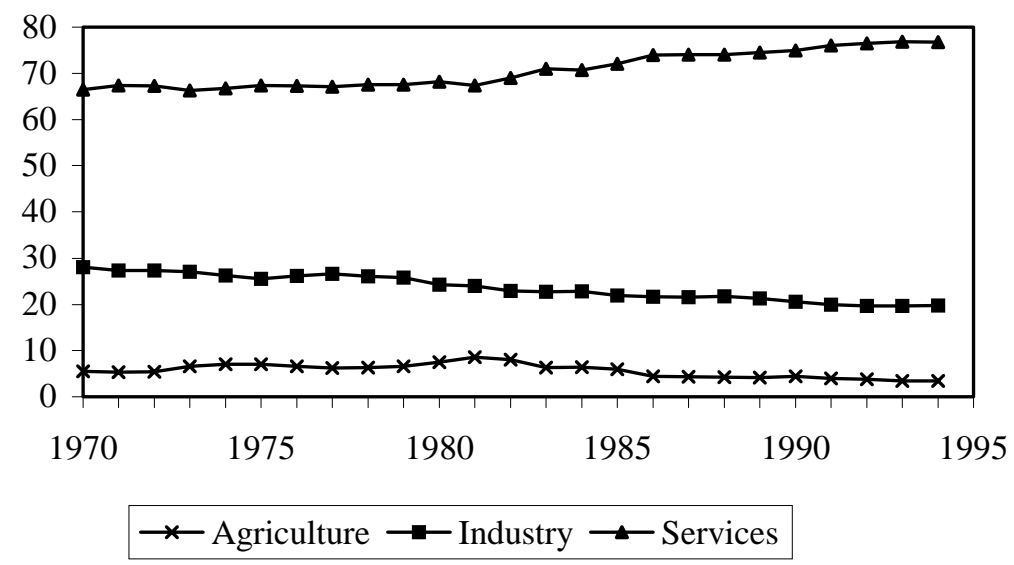


Figure 3 Sectoral employment shares, 1970-1995

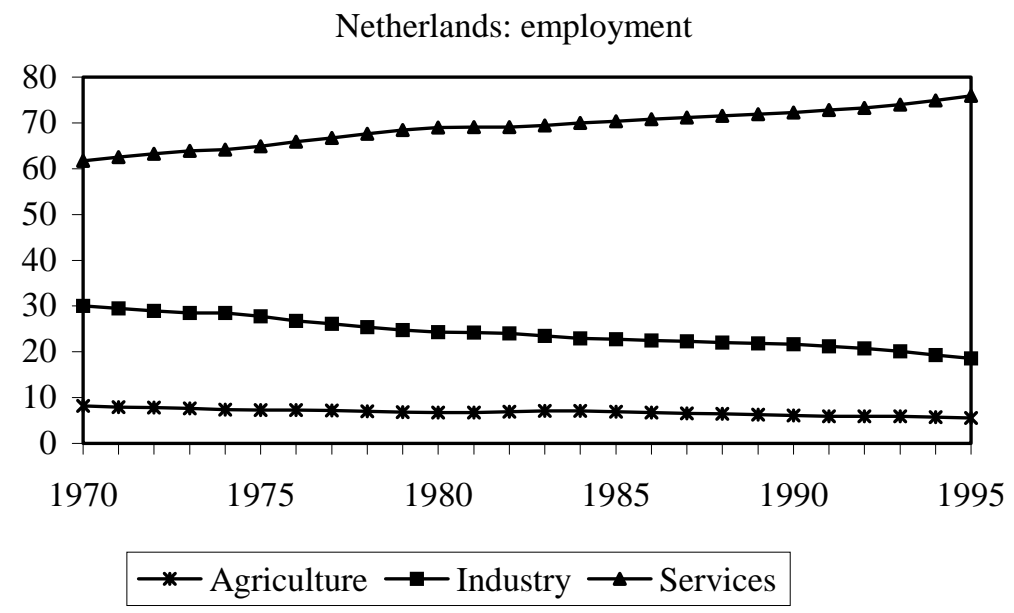

Germany: employment

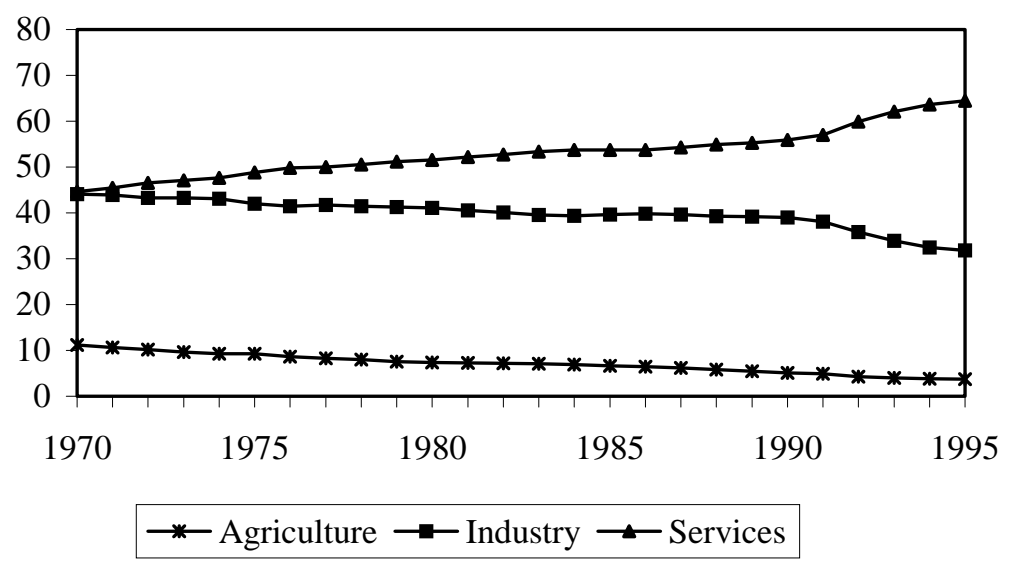

United States: employment

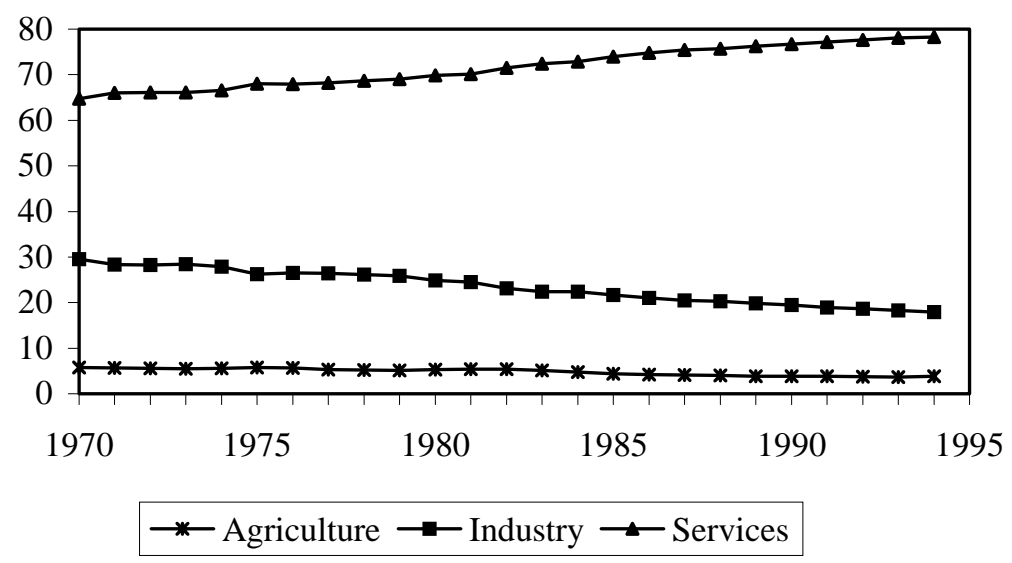


Figure 4 Metal industries: GDP shares, 1970-1995

Netherlands

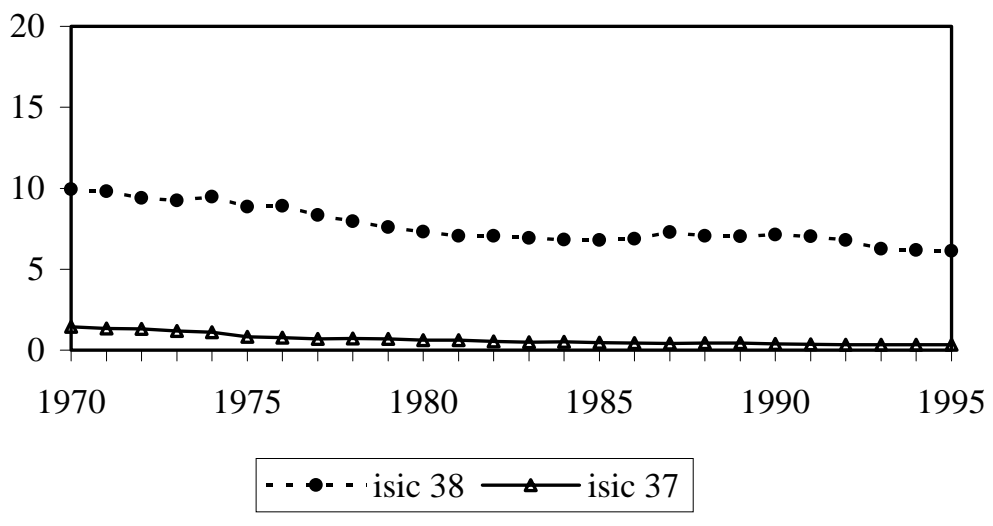

Germany

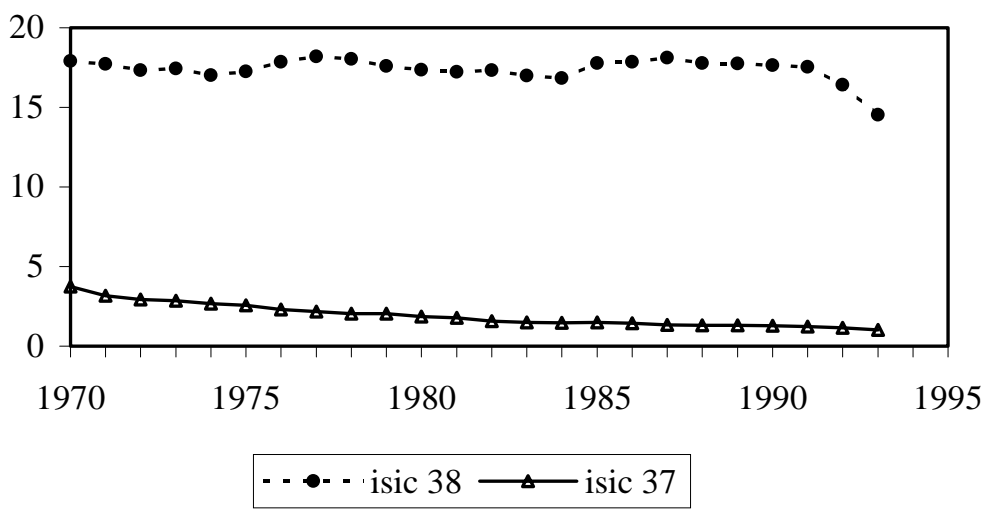

United States

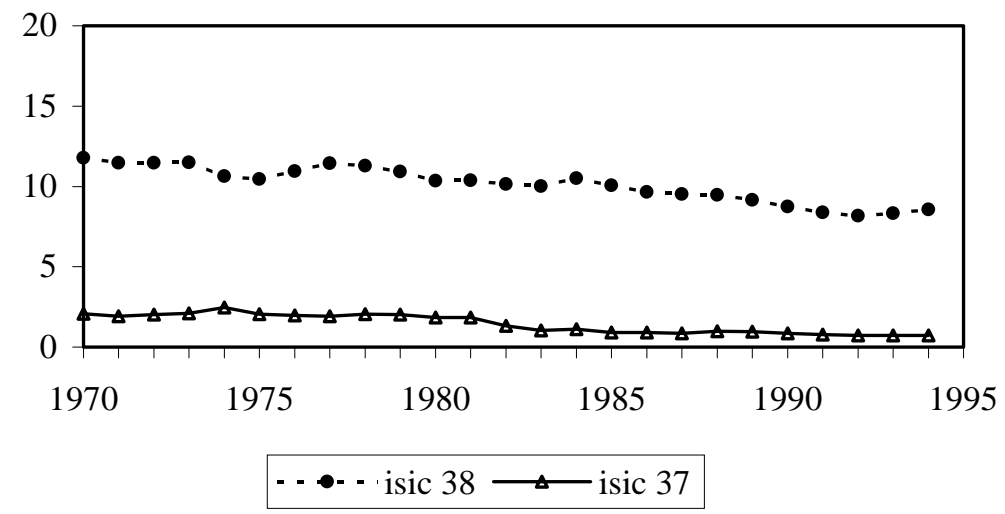


Figure $5 \quad$ R\&D intensities Dutch and German manufacturing industries, 1973 - 1994

R\&D intensity Manufacturing (ISIC 3)

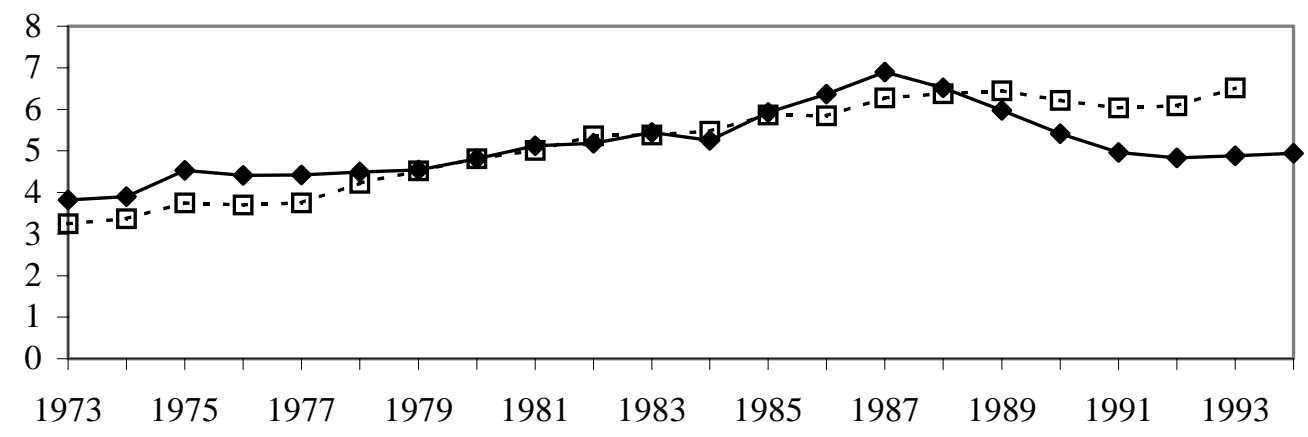

R\&D intensity Basic metal industires (ISIC 37)

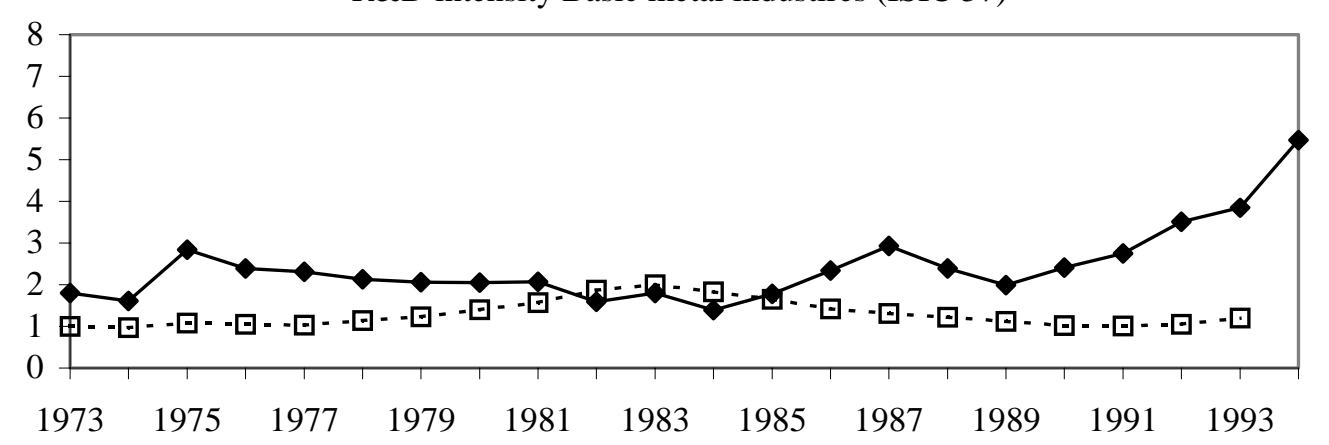

R\&D intensity Fabricated metal products (ISIC 38)

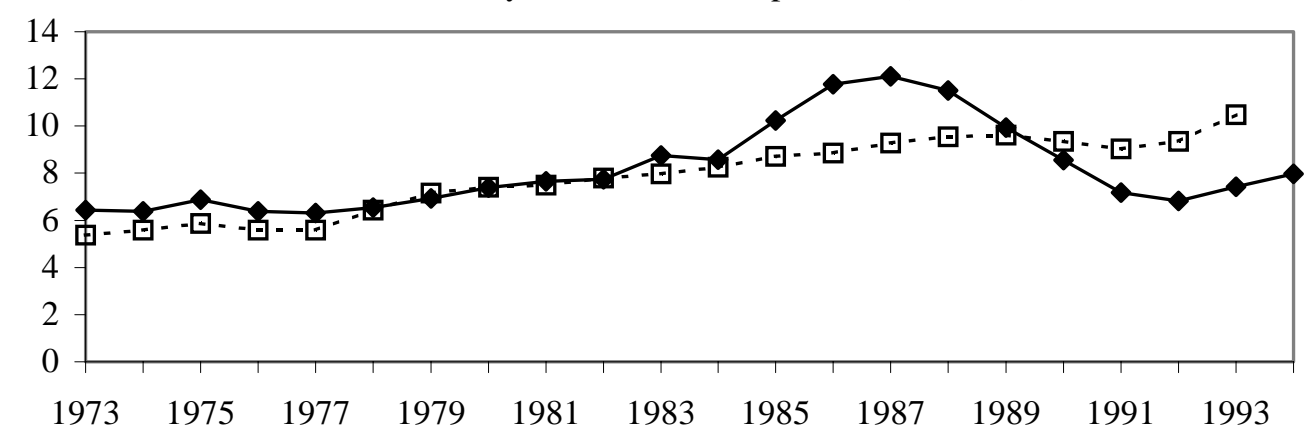

R\&D intensity Metal industries (ISIC 37+38)

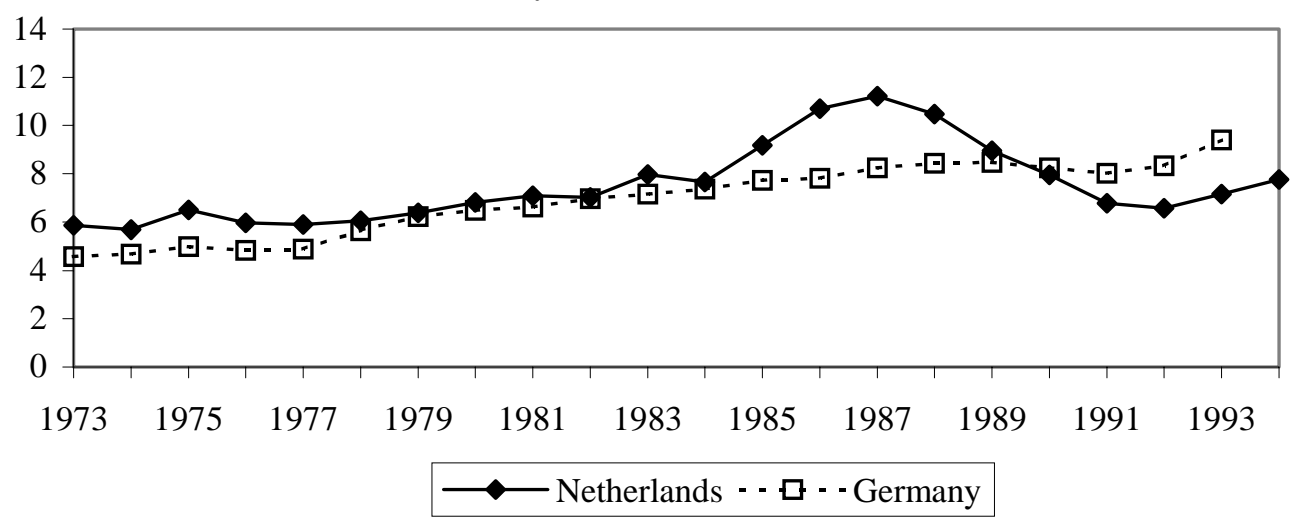


Figure 6 Labour productivity (output per employee), 1970-1995
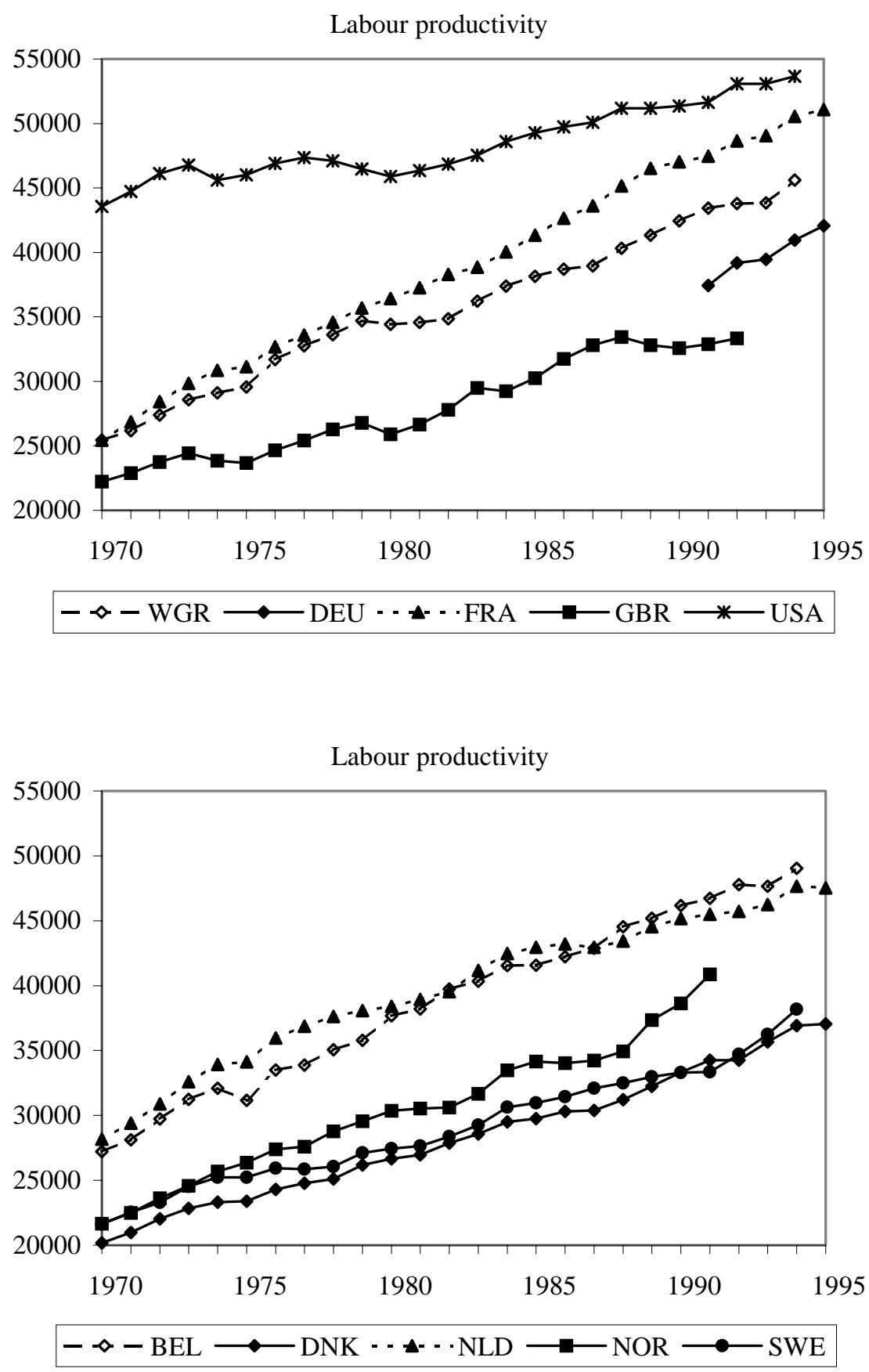
Figure 7 Labour productivity (output per man-hour), 1970-1995
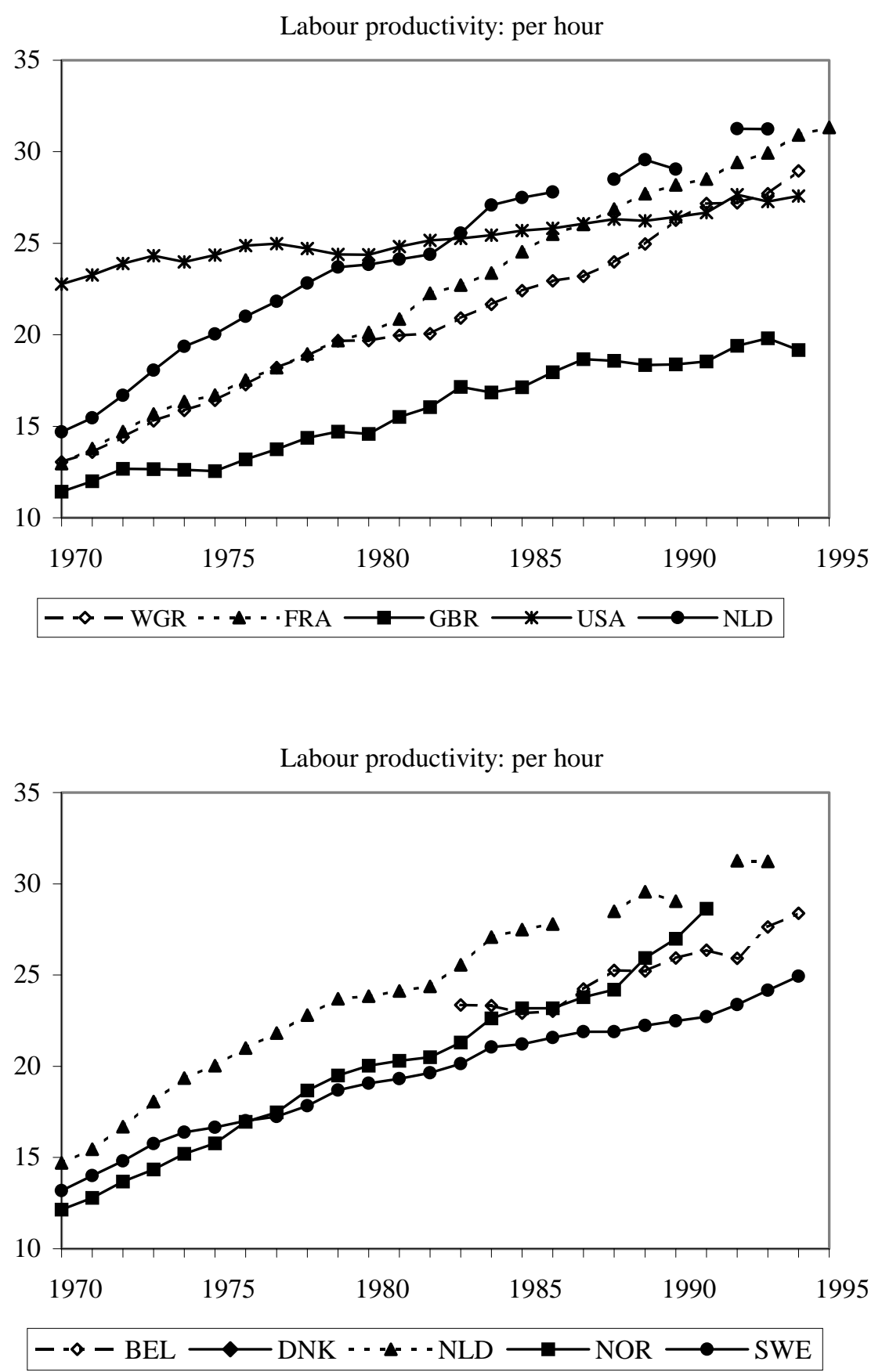
Figure 8 Labour productivity: Industry vs. Services

Netherlands

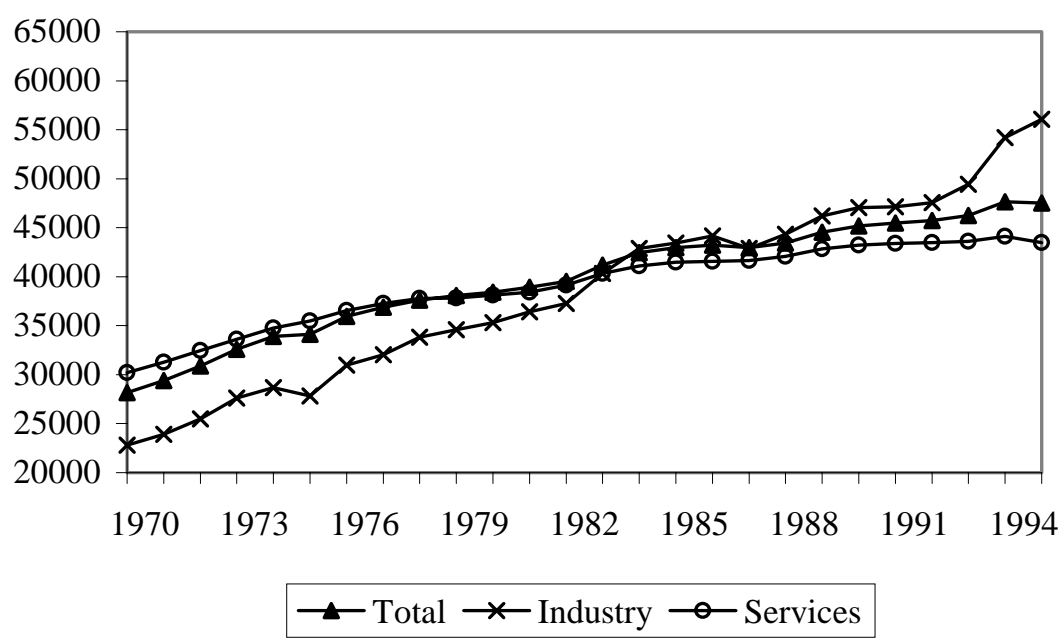

Germany

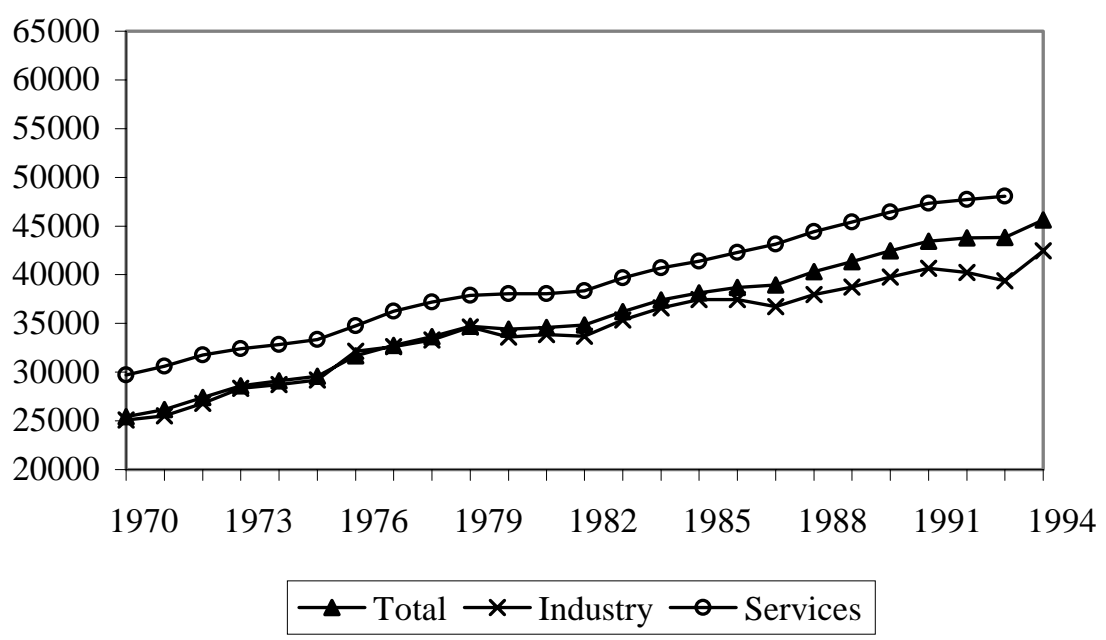

United States

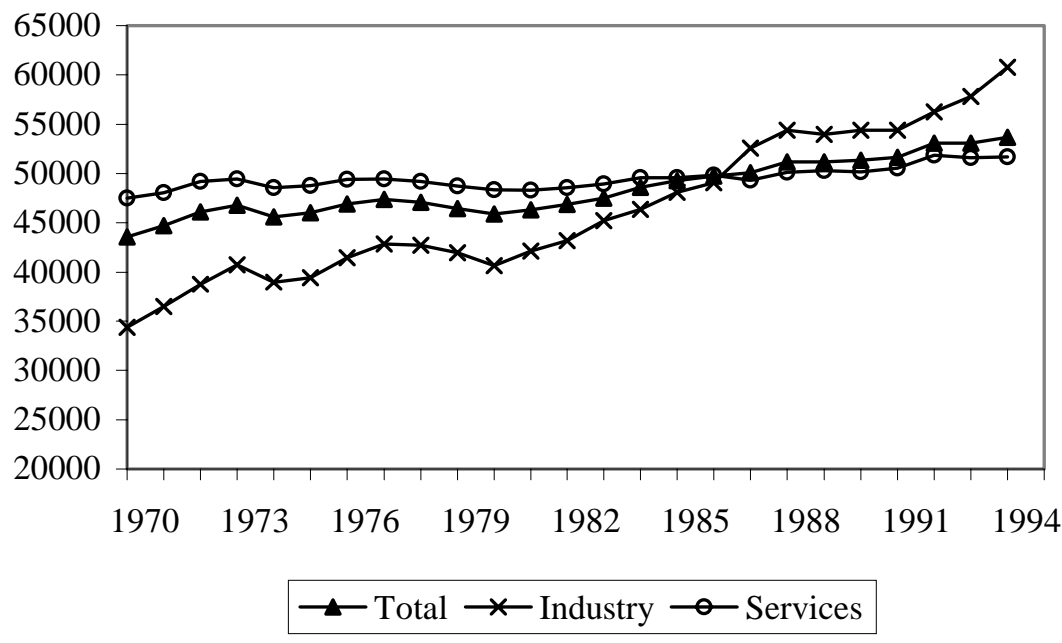


Table 1 Relative GDP growth in the Netherlands compared to other Western European countries

\begin{tabular}{lrrrrrrrrrrrrrrr}
\hline & 1970 & 1971 & 1972 & 1973 & 1974 & 1975 & 1976 & 1977 & 1978 & 1979 & 1980 & 1981 & 1982 & 1983 & 1984 \\
\hline AUT & 1.43 & 0.89 & 2.90 & 0.20 & -0.02 & -0.27 & -0.54 & 2.04 & -1.94 & 2.34 & 2.15 & -1.04 & 3.25 & 1.07 & -3.25 \\
BEL & 0.65 & -0.47 & 2.04 & 1.28 & 0.21 & -1.35 & 0.55 & -1.74 & 0.41 & -0.21 & 3.28 & -2.75 & 2.66 & -1.35 & -1.15 \\
DNK & -3.67 & -1.56 & 1.97 & -1.06 & -4.90 & -0.57 & 1.35 & -0.70 & -0.98 & 1.17 & -1.31 & -2.36 & 4.06 & 1.11 & 1.11 \\
NOR & -2.16 & 0.64 & -0.17 & 0.56 & 0.59 & 2.57 & -1.32 & -0.05 & 1.15 & 5.08 & 7.82 & 12.09 & 1.08 & 1.27 & 4.23 \\
SWE & 0.78 & -3.28 & -1.02 & -0.72 & -0.77 & 2.64 & -4.06 & -3.91 & -0.71 & 1.47 & 0.81 & 0.94 & 1.73 & 0.69 & 0.37 \\
DEU & -0.55 & -1.33 & 0.90 & 0.00 & -3.69 & -1.50 & 0.29 & 0.63 & 0.42 & 1.78 & 0.50 & -0.57 & 0.65 & -0.05 & -0.82 \\
FRA & 0.04 & 1.19 & 2.59 & 0.68 & -0.73 & 0.57 & -0.88 & 0.90 & 0.89 & 0.87 & 0.76 & 0.80 & 3.79 & -1.26 & -1.81 \\
GBR & -3.38 & -1.52 & -1.02 & 2.93 & -4.96 & -0.48 & -1.34 & -1.25 & 1.12 & -0.26 & -2.96 & -1.13 & 2.70 & 2.22 & -0.89 \\
& & & & & & & & & & & & & & & \\
& 1985 & 1986 & 1987 & 1988 & 1989 & 1990 & 1991 & 1992 & 1993 & 1994 & 1995 & 1996 & 1997 & 1998 & \\
\hline AUT & -0.22 & -0.86 & 0.07 & 1.30 & -0.83 & 0.53 & 1.19 & -0.63 & -0.23 & -1.17 & -0.01 & -1.83 & -1.11 & -0.72 \\
BEL & -2.02 & -1.25 & 0.70 & 2.45 & -1.17 & -0.96 & -0.50 & -0.73 & -2.15 & -1.04 & 0.28 & -1.85 & -0.61 & -1.03 & \\
DNK & 1.01 & 1.31 & -1.28 & -0.88 & -4.33 & -2.99 & -0.66 & -1.89 & 0.62 & 0.74 & 0.63 & -0.62 & -0.10 & -1.54 & \\
NOR & 0.66 & -6.91 & -1.42 & -3.53 & -1.96 & -2.34 & 0.38 & -2.15 & 2.15 & 0.14 & 2.14 & 3.94 & 0.68 & -0.74 & \\
SWE & -0.60 & -0.64 & 1.28 & 0.31 & -2.58 & -2.78 & -3.40 & -3.59 & -3.04 & 0.33 & 1.45 & -2.02 & -1.11 & -1.06 & \\
DEU & -0.97 & -0.02 & -0.25 & 1.31 & -1.05 & 1.51 & 10.06 & 0.35 & -2.27 & -0.30 & -0.33 & -1.79 & -0.66 & -0.99 & \\
FRA & -1.28 & -0.19 & 0.45 & 2.04 & -0.85 & -1.77 & -1.21 & -1.49 & -1.74 & -0.79 & 0.12 & -1.75 & -0.55 & -0.65 & \\
GBR & 0.80 & 1.18 & 3.15 & 2.90 & -2.51 & -3.80 & -4.31 & -2.34 & 1.11 & 0.78 & 0.54 & -0.74 & 0.04 & -1.55 & \\
\hline
\end{tabular}

Source: MERIT, data: OECD.

Table 2 Netherlands, labour productivity, average growth

\begin{tabular}{lcc}
\hline & Per employee & Per man-hour \\
\hline $1981-1985$ & 2.28 & 2.91 \\
$1986-1990$ & 1.01 & 1.12 \\
$1991-1995$ & 1.03 & $2.47^{\mathrm{a}}$ \\
\hline
\end{tabular}

a 1991-1993 